\title{
Virus-mediated total release of dimethylsulfoniopropionate from marine phytoplankton: a potential climate process
}

\author{
Richard W. Hill ${ }^{1, *}$, Bradley A. White ${ }^{1}$, Matthew T. Cottrell ${ }^{2, * *}$, John W. H. Dacey ${ }^{3}$ \\ ${ }^{1}$ Department of Zoology, Michigan State University, East Lansing, Michigan 48824, USA \\ ${ }^{2}$ Marine Science Institute, University of Texas at Austin, Port Aransas, Texas 78373, USA \\ ${ }^{3}$ Department of Biology, Woods Hole Oceanographic Institution, Woods Hole, Massachusetts 02543, USA
}

\begin{abstract}
Growing, axenic cultures of the eukaryotic marine microalga Micromonas pusilla (Prasinophyceae) were inoculated with 0.7 infectious particles cell ${ }^{-1}$ of the viral pathogen MPV (Micromonas pusilla virus). Starting 11 to $14 \mathrm{~h}$ after the inoculation, rapid release of intracellular dimethylsulfoniopropionate (DMSP) to the dissolved pool occurred along with cell lysis. DMSP release was total. Release facilitates bacterial degradation of DMSP to dimethylsulfide, a gas that affects cloud cover over the oceans. Viruses of eukaryotic manne phytoplankton may thus participate in the biological shaping of global climate.
\end{abstract}

KEY WORDS: Dimethylsulfide - Dimethylsulfoniopropionate Algal virus - Micromonas pusilla $\cdot$ MPV

\section{INTRODUCTION}

The atmospheric trace gas dimethylsulfide (DMS) is believed to affect cloud cover and global climate (Shaw 1983, Charlson et al. 1987, Andreae 1990, Bates et al. 1992. Malin et al. 1992, Charlson 1995, Malin 1996). Eukaryotic marine phytoplankton that synthesize dimethylsulfoniopropionate (DMSP), a nonvolatile DMS precursor, appear to be the principal source of DMS (Keller et al. 1989a). DMS is formed from DMSP by enzymatic cleavage. Although some phytoplankton possess a DMSP lyase (Stefels \& van Boekel 1993, Steinke et al. 1996), the principal agents of DMS formation from DMSP in the oceans are believed to be free-living heterotrophic microbes, of which bacteria (Visscher et al. 1992, Ledyard \& Dacey 1994, Taylor \& Visscher 1996) are best described. Although the climate effects of DMS are being eclipsed in certain regions of the globe by burgeoning anthropogenic sulfur emissions, DMS remains important where anthro-

\footnotetext{
•E-mail: hillr@pilot.msu.edu

-Present address: College of Marine Studies, University of Delaware, Lewes, Delaware 19958, USA
}

pogenic influences are not overwhelming (Bates et al. 1992, Falkowski et al. 1992, Charlson 1995, Malin 1996). DMS accounts for over half of all nonanthropogenic gaseous sulfur input to the atmosphere (Andreae 1990, Bates et al. 1992)

Intense interest has developed in processes that accelerate conversion of phytoplanktonic intracellular DMSP to extracellular DMS because of the potential of these processes to increase surface-water DMS concentrations and force greater DMS flux to the atmosphere. Two major processes are known: grazing on algal cells by small planktivores (Dacey \& Wakeham 1986, Leck et al. 1990, Wolfe et al. 1994, Christaki et al. 1996) and algal senescence (Nguyen et al. 1988, Malin et al. 1992, Stefels \& van Boekel 1993).

We reasoned that viral lysis of algae might be a third major process that could accelerate DMS formation, because lysis could cause intracellular DMSP to be released to the water and thus promote bacterial degradation to DMS (Kiene 1990, Visscher et al. 1992). The potential importance of marine algal viruses has been appreciated only recently. Although virus-like particles (VLPs) were reported in pro- and eukaryotic phytoplankton at the start of the 1970 s (Fuhrman \& 
Suttle 1993), infectivity and lysis were not demonstrated until the end of that decade (Mayer \& Taylor 1979). The high abundance and diversity of viruses of marine phytoplankton became fully clear only around 1990 (Proctor \& Fuhrman 1990, Suttle et al. 1990). This knowledge has heightened interest in the ecological and biogeochemical roles played by algal viruses (Fuhrman 1992, Reisser 1993).

A previous, descriptive study of viruses and DMSP (Bratbak et al. 1995) yielded ambiguous results (due, e.g., to uncertainty about virus identity and pathogenicity). We adopted an experimental approach using a defined alga-virus system and employing axenic algal cultures so that virus-mediated processes could be observed unconfounded by bacterial processes. We found that viral lysis of DMSP-synthesizing eukaryotic phytoplankton releases the entire intracellular DMSP pool to the water. This result demonstrates for the first time that viruses are potentially a component of the biological system that affects marine climate via sulfur biogeochemistry.

\section{MATERIALS AND METHODS}

Biological materials. We chose the microflagellate Micromonas pusilla (Prasinophyceae) and its speciesspecific viral pathogen MPV (Mayer \& Taylor 1979) for our experiments because this alga and virus constitute the best-defined host-virus system known for marine eukaryotic algae (Cottrell \& Suttle 1991). The axenic algal culture was derived by one of us (Cottrell \& Suttle 1993) from $M$. pusilla strain LB991 [University of Texas Culture Collection of Algae (Starr \& Zeikus 1993)]. A clone of the culture has been deposited at the Provasoli-Guillard Center for Culture of Marine Phytoplankton (Cottrell \& Suttle 1993). The material we used had been maintained at the University of Texas at Austin Marine Science Institute since production of the axenic culture there. The axenic state of the culture during experiments was confirmed by use of phasecontrast microscopy, acridine orange staining, and a Difco-AC-broth-based purity test medium. The virus employed was a clone of MPV isolated from seawater collected at Scripps Pier (La Jolla, California, USA) and designated MPV-SPi (Cottrell \& Suttle 1991, 1995).

Procedure. The vessels for experiments were autoclaved 11 Erlenmeyer flasks sealed with silicon-rubber stoppers equipped with sterile sampling ports. The stoppers and ports were selected and designed to maximize DMS retention, and preliminary tests demonstrated that the vessels retained $>90 \%$ of added DMS for $40 \mathrm{~h}$. Each vessel was filled with sterile artificial seawater (Cottrell \& Suttle 1991) and inoculated with axenic algal culture (total liquid volume: $700 \mathrm{ml}$; head- space: $373 \mathrm{mll}$ ) $43 \mathrm{~h}$ before experiments began. Vessels were maintained at 22 to $24^{\circ} \mathrm{C}, 58 \mathrm{~cm}$ from a bank of Philips cool white fluorescent bulbs (photosynthetically active radiation averaged $50 \mu \mathrm{mol}$ quanta $\mathrm{m}^{-2}$ $\mathrm{s}^{-1}$ ). Algal populations were growing rapidly in the vessels at the start of experiments. At time 0,7 vessels were inoculated with virus, whereas 3 control vessels received no viral addition. Each inoculated vessel received 25 to $28 \mathrm{ml}$ of a viral lysate $\left[4.2 \times 10^{8}\right.$ infectious particles $\mathrm{ml}^{-1}$ estimated by most probable number assay (Cottrell \& Suttle 1995)] prepared by complete lysis of a high-density Micromonas pusilla culture. As it was injected, the lysate added to each vessel was filtered through a sterile Millipore polyvinylidene difluoride Durapore HVLP filter ( $0.45 \mu \mathrm{m}$ pore diameter) to avoid adding bacteria to the axenic culture. The dose inoculated into each vessel was 0.7 infectious particles per algal cell (calculated assuming $65 \%$ passage of virus through the filter, as measured previously). Periodically, $14 \mathrm{ml}$ of culture was aseptically withdrawn from each inoculated and control vessel. Part of each sample $(8 \mathrm{ml})$ was used to measure algal cell density. The remainder $(6 \mathrm{ml})$ was immediately filtered through a Whatman GF/F glass-fiber filter [nominal pore size: 0.6 to $0.7 \mu \mathrm{m}$ (Koike et al. 1990)] directly into a sealed $12 \mathrm{ml}$ glass vial. Filtration was performed as gently as possible while keeping duration to $<90 \mathrm{~s}$; filters were wetted with artificial seawater before use, and low suction was employed (pressure differential: $10 \mathrm{~cm} \mathrm{H}_{2} \mathrm{O}$, continuously monitored). Fluorometry (Turner 10-AU Fluorometer at maximal sensitivity) demonstrated that filtrate from this procedure was chlorophyll-free, indicating full retention of algal cells by the filter.

Measurement of DMSP and DMS. DMSP within algal cells in each sample of culture (termed particulate DMSP) was quantified by measuring the DMSP retained by the filter. Extracellular DMSP (termed dissolved DMSP) was measured in the filtrate, as was DMS. To measure DMS, a $1 \mathrm{ml}$ subsample of each filtrate was sparged promptly after filtration to extract the DMS, which was cryotrapped on Tenax (Alltech) at $-15^{\circ} \mathrm{C}$ and later desorbed by heating. DMSP, whether particulate or dissolved, was converted to DMS by alkali for assay (Dacey \& Blough 1987); to this end, $5 \mathrm{ml}$ of filtrate was made $2 \mathrm{~N}$ in $\mathrm{KOH}$, the filter was placed in $2 \mathrm{~N} \mathrm{KOH}$, and both preparations were incubated in glass vials with teflon-coated butyl-rubber septa (Regis Technologies). DMS in all samples was quantified by gas chromatography (Supelco Chromosil 330 column, Sievers $350 \mathrm{~B}$ chemiluminescence detector, Hewlett Packard 3390A integrator) using standards prepared with pure DMS (Fluka) in background solutions identically matched to the several types of samples assayed. Native DMS in filtrates was subtracted from total DMS 
measured after treatment with alkali to calculate dissolved DMSP. All calculations recognized partitioning of DMS between liquid and gas phases.

Measurement of cell density. Algal cell density was assayed by fluorometry (Turner 10-AU Fluorometer) (Cottrell \& Suttle 1991). Direct cell counts were performed on a subset of samples using a hemacytometer following Lugol's fixation. Cell density estimates by the 2 methods were highly related $\left(r^{2}=0.9\right)$ (Cottrell \& Suttle 1991), and for samples assayed by fluorometry alone, the regression was used to calculate cell numbers per volume (as in Fig. 1).

\section{RESULTS AND DISCUSSION}

Viral infection and lysis, as shown in Fig. 1A, caused rapid decline of algal cell density and particulate DMSP starting 11 to $14 \mathrm{~h}$ after inoculation. Dissolved DMSP increased simultaneously, indicating that as algal cells were lysed, DMSP was released.

After reaching a peak at 11 to $14 \mathrm{~h}$ after inoculation, the sum of particulate and dissolved DMSP in virus-inoculated cultures (Fig. 1A) remained constant (1899 to $2052 \mathrm{nmol} \mathrm{l}^{-1}$ ) throughout the phase of massive lysis from 14 to $35 \mathrm{~h}$. This constancy strongly suggests that release of DMSP from virally lysed cells was total, with no conversion of DMSP to DMS or other products. The use of axenic algal cultures meant that DMSP-degrading bacteria were not present. In addition, experiments we performed with chemically pure DMSP added to axenic Micromonas pusilla demonstrated that this alga does not itself form DMS from DMSP.

Control cultures, as seen in Fig. 1B, continued to grow and produce particulate DMSP beyond the time that virus-inoculated cultures started to plummet. The controls entered stationary phase, and senescent liberation of DMSP (Nguyen et al. 1988, Malin et al. 1992, Stefels \& van Boekel 1993) was observed.

Rapid release of DMSP from algal cells by viral infection and lysis was confirmed by over 30 additional replicate tests carried out on virus-inoculated cultures of Micromonas pusilla strain LB991. As noted before, LB991 was the originating strain for our axenic culture (Cottrell \& Suttle 1995). Strain LB991 itself, however, is not axenic; as is true of most culture-center strains, the alga coexists with a bacterial community descended, at least in part, from bacteria present at the time of original isolation. Fig. 2 shows a typical outcome for an experiment with LB991. The results suggest that the bacterial community in LB991 includes organisms that catabolize DMSP, accumulate DMSP, and catabolize DMS. The dramatic contrast between outcomes in Figs. 1 \& 2 itself offers strong evidence that our axenic

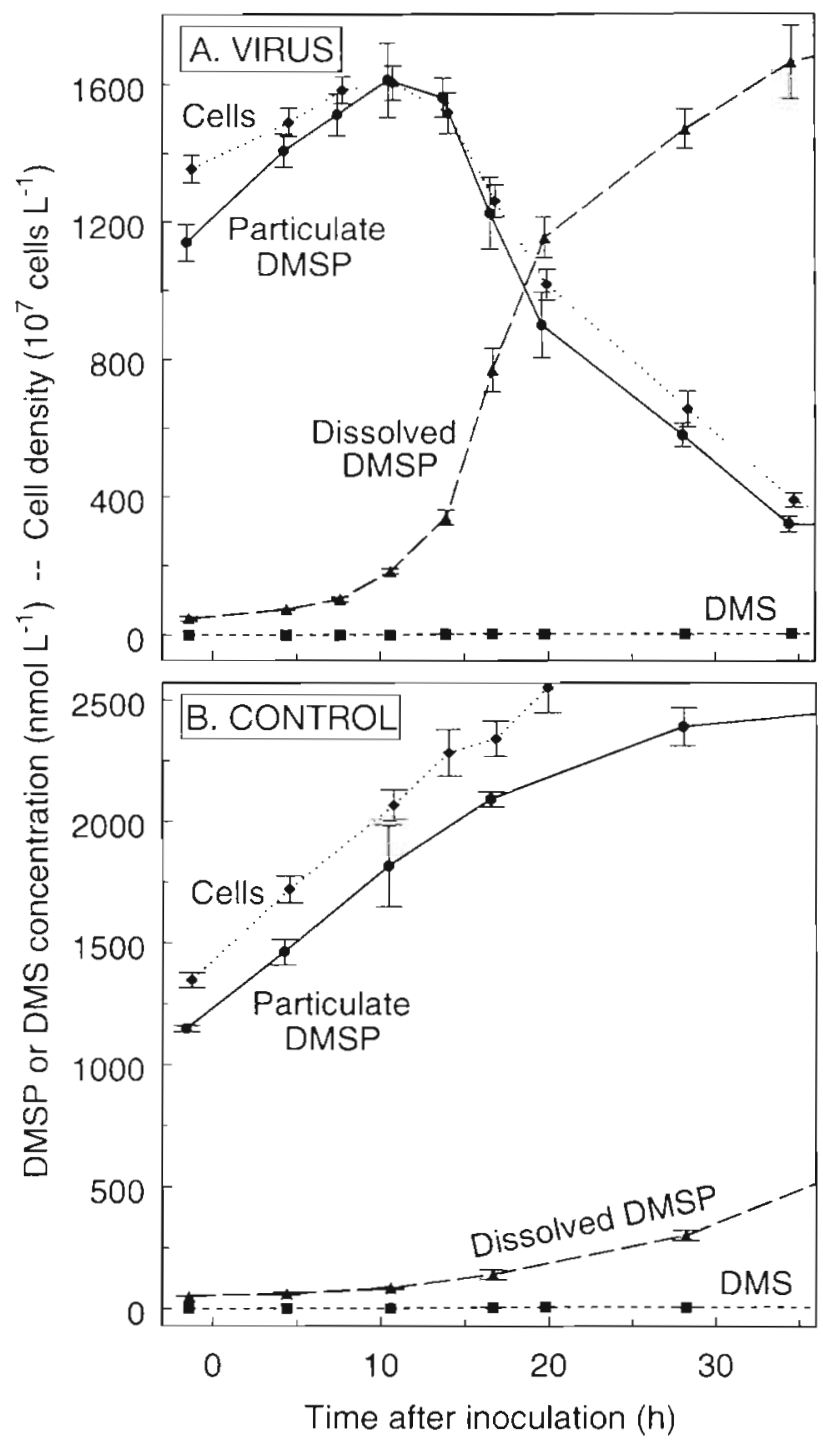

Fig. 1. Concentrations of particulate (i.e. cellular) and dissolved dimethylsulfoniopropionate (DMSP) and dimethylsulfide (DMS), and algal cell density, as functions of time $(A)$ in axenic algal cultures $(N=7)$ inoculated with virus at time zero and $(\mathrm{B})$ in control axenic cultures $(\mathrm{N}=3)$ that were not inoculated. Error bars depict standard deviations. (-) Particulate DMSP; ( $\mathbf{\wedge}$ ) dissolved DMSP; ( $\mathbf{\square})$ DMS; $(\bullet)$ cell density. Some times are shifted slightly for clarity. Dissolved DMSP is defined operationally as that passing a Whatman GF/F filter (Koike et al. 1990, Proctor \& Fuhrman 1991); portions could consist of particles or colloids smaller than 0.6 to $0.7 \mu \mathrm{m}$ (Koike et al. 1990). Cell density was not measured after $20 \mathrm{~h}$ in controls. Sampling continued for $60 \mathrm{~h}$ after inoculation, but

to emphasize critical results, only the first $36 \mathrm{~h}$ is shown

algal cultures were free of microbes that metabolize DMSP or DMS. A highly instructive aspect of the experiments with LB991 is that the rise of dissolved DMSP caused by viral lysis was always followed in about $10 \mathrm{~h}$ by a marked rise in DMS (Fig. 2A). The magnitude and time course of the DMS rise (and other 


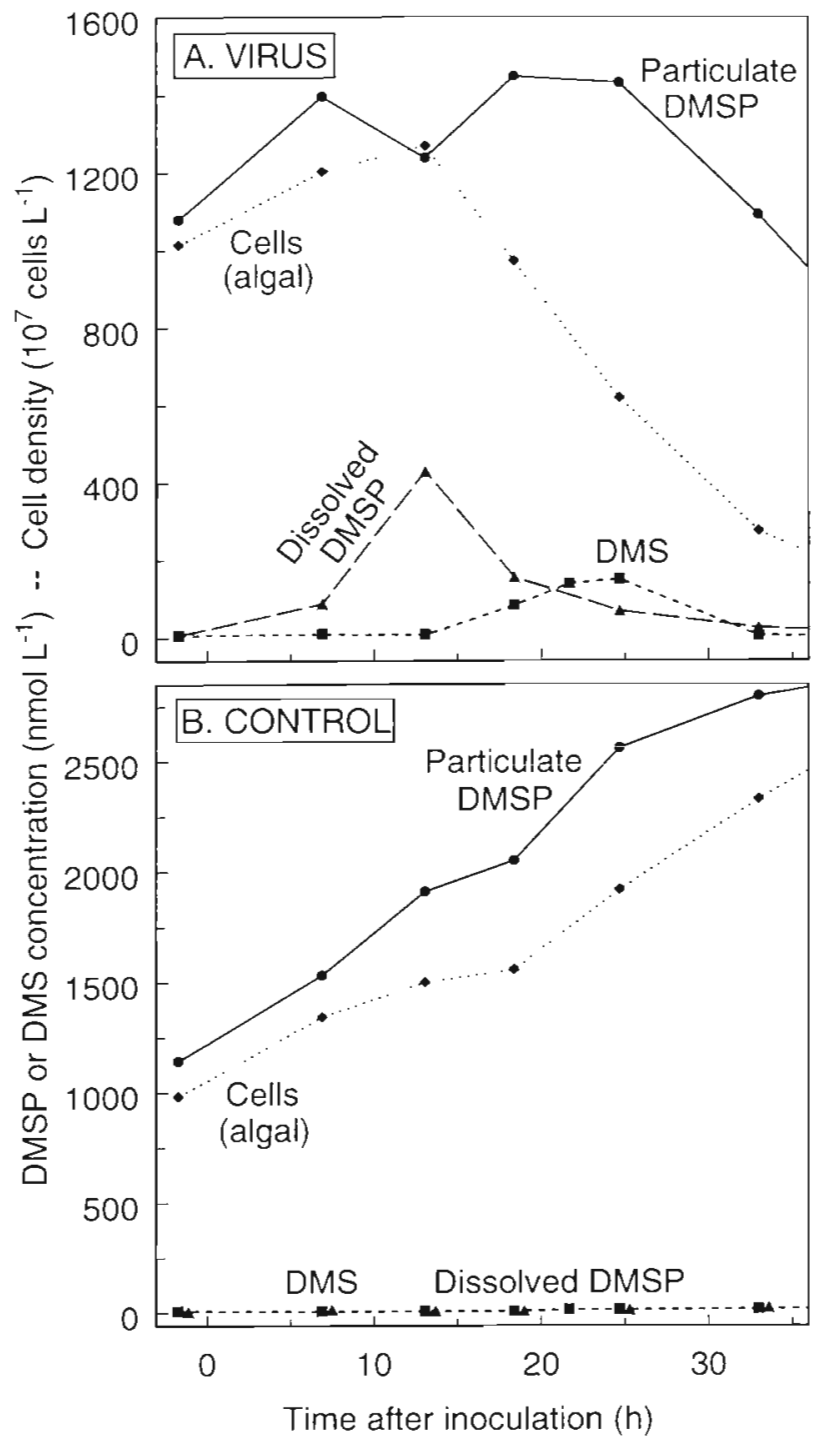

Fig. 2. Typical results for (A) LB991 cultures inoculated with virus and $(B)$ controls, shown in the format of Fig. 1. Each panel presents a single culture. Note that in virus-inoculated LB991, the rise of dissolved DMSP is truncated by comparison to virus-inoculated axenic cultures. Some dissolved DMSP is microbially degraded to DMS; much, we hypothesize, is accumulated by microbes that are retained by a Whatman GF/F filter. The rise of DMS is itself terminated, presumably by DMS-catabolizing microbes. In control LB991, unlike control axenic cultures, no accumulation of dissolved DMSP occurs, presumably because of the same microbial processes that truncate the rise of dissolved DMSP in a lysed culture. Times for dissolved DMSP in the control are shifted forward slightly for clarity. Sampling continued for $56 \mathrm{~h}$ after inoculation, but to emphasize critical results, only the first $36 \mathrm{~h}$ is shown

details of bacterial DMSP processing) were specific to the particular bacterial community in LB991. Thus, they cannot be extrapolated to natural waters. However, the DMS rise demonstrates concretely that algal DMSP becomes susceptible to bacterial degradation when viral lysis releases the DMSP from algal cells. The results also illustrate more generally the potential importance of viral lysis in promoting bacterial breakdown of algal organic matter. Lytic viruses have been frequently hypothesized to be biogeochemical agents that facilitate bacteria-mediated catabolism (e.g. remineralization) of the cell contents of host cells (Proctor \& Fuhrman 1990, 1991, Fuhrman \& Suttle 1993, Reisser 1993, Milligan \& Cosper 1994). To our knowledge, our data on DMS production in lysed LB991 provide the first published, direct evidence of this role for marine phytoplankton viruses.

The data on axenic algal cultures in Fig. 1 demonstrate, specifically, that when DMSP-synthesizing phytoplankton are lysed by viruses, the release of their DISP is total. The entire quantity is thus made available to metabolism by the local bacterial community. One reason we believe the characterization of this viral effect is an important finding is the recent discovery of increasing numbers of viruses of DMSP-synthesizing eukaryotic phytoplankton. The Micromonas-MPV system described here may itself be significant on a global scale because both the alga and virus have cosmopolitan distributions (Cottrell \& Suttle 1991). In just the last $4 \mathrm{yr}$, viruses (Table 1) have also become known for phytoplankton in the genera Aureococcus, Chrysochromulina, Emiliania, and Phaeocystis, the last 3 of which are well known as important DMSP producers (Keller et al. 1989b, Liss et al. 1994). Viral lysis leading to total DMSP release may be a common fate for DMSP-synthesizing phytoplankton, indicating that marine algal viruses may be a component of the biological system that shapes global climate via impacts on sulfur flux.

A field study of Micromonas and MPV in an enclosed coastal basin (Cottrell \& Suttle 1995) indicated that the alga and virus maintain a stable coexistence, with MPV lysing possibly up to $50 \%$, but more likely 2 to $10 \%$, of cells $\mathrm{d}^{-1}$. The effect of such steady cropping on productivity of DMSP is not necessarily negative. Much as Fuhrman (1992) has argued for bacterial populations, daily lysis of a fraction of algal numbers could enhance algal productivity - and thus DMSP productivity-by hastening cell turnover and nutrient recycling. In the coastal basin, the lysis rate of Micromonas reached $6 \times 10^{5}$ cells $\mathrm{l}^{-1} \mathrm{~d}^{-1}$. The immediate effect of lysis was thus acceleration of DMSP flux to the dissolved pool by as much as $1 \mathrm{nmol} \mathrm{l}^{-1}$ every $12 \mathrm{~d}$ [calculated by use of a cellular DMSP content intermediate between our value and that previously published (Keller et al. 1989a)]. More-rapid releases of DMSP may accompany virus-induced bloom collapses. Data on collapses of Emiliania huxleyi blooms indicate that a $180 \mathrm{~nm}$ diameter virus can account for 25 to $100 \%$ of mortality and elevation of dissolved DMSP by 13 to 
Table 1. Described viruses of DMSP-synthesizing marine phytoplankton"

\begin{tabular}{|c|c|c|c|c|c|}
\hline Hosts & 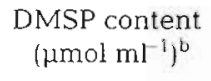 & Designation & $\begin{array}{l}\text { Virus } \\
\text { Type }\end{array}$ & $\operatorname{Size}^{c}(\mathrm{~nm})$ & $\begin{array}{l}\text { Report date } \\
\text { (source) }^{\text {d }}\end{array}$ \\
\hline Micromonas pusilla & 225 & MPV & DNA & 133 & $1979(1)$ \\
\hline Emiliania huxleyi & 166 & - & $?$ & 180 & $1993(2)$ \\
\hline Aureococcus anophagefferens & 231 & - & DNA & 60 & $1994(3)$ \\
\hline Chrysochromulina brevifilum and strobilus & 332 & $\mathrm{CbV}$ & DNA & 158 & 1995 (4) \\
\hline Phaeocystis pouchetii & 187 & $\mathrm{PpV}$ & DNA & 145 & $1996(5)$ \\
\hline \multicolumn{6}{|c|}{$\begin{array}{l}\text { "Only viruses for which propagation has been reported are listed. The following additional genera are found both on lists of } \\
\text { DMSP-synthesizing taxa (Keller et al. 1989a) and on lists of taxa exhibiting VLPs (Reisser 1993): Coccolithus, Cryptomonas, } \\
\text { Hymenomonas, Nannochloropsis, and Tetraselmis }\end{array}$} \\
\hline \multirow{2}{*}{\multicolumn{6}{|c|}{$\begin{array}{l}\text { bValues are per ml of cellular volume; all taken, for consistency, from Keller et al. (1989a, b). Values for Chrysochromulina and } \\
\text { Phaeocystis are for congeners }\end{array}$}} \\
\hline & & & & & \\
\hline${ }^{\mathrm{d}}$ (1) Mayer \& Taylor (1979); (2) Bratbak etal. (1 & 993); (3) Milligan & $\operatorname{sper}(1994) ;(4$ & & & \\
\hline
\end{tabular}

$50 \mathrm{nmol} \mathrm{l}^{-1}$ in just a few days (Keller et al. 1989a, Bratbak et al. 1993). To provide perspective, concentrations of DMS in ocean surface waters average $3 \mathrm{nmol} \mathrm{l}^{-1}$ (Andreae 1990), and concentrations of dissolved DMSP are commonly 2 to $25 \mathrm{nmol} \mathrm{l}^{-1}$ (Iverson et al. 1989). Because many host-virus systems presumably exist in natural waters (Suttle et al. 1990, Reisser 1993, Milligan \& Cosper 1994, Suttle \& Chan 1995, Jacobsen et al. 1996), the summed impact of all algal viruses may be many times greater than calculated here for single host-virus systems.

The mechanisms and rates of DMSP release from phytoplankton are likely to be key parameters in DMSmediated climate modulation. The surface-water DMS concentration, which is the principal immediate determinant of DMS flux to the atmosphere (Andreae 1990 , Malin et al. 1992, Malin 1996), is not a simple product of the amount of DMSP synthesis by phytoplankton. Instead, it depends on multiple dynamically interacting processes that make and remove DMS and divert DMSP to other products. These processes include the bacterial degradation of DMSP to DMS already noted, bacterial catabolism of DMSP to other products (Visscher et al. 1992, Taylor \& Visscher 1996), and both biological (Kiene \& Bates 1990, Taylor \& Visscher 1996) and chemical (Brimblecombe \& Shooter 1986) destruction of DMS. Within a matrix of processes such as this, the concentration of any component at any time depends on dynamic interactions. The surface-water DMS concentration depends not just on how much DMSP is made, but on the times, sites, and rates of release of the DMSP from algal cells. Viruses may affect all 3 of these dynamically critical parameters in ways distinct from other DMSP-release mechanisms, especially because of their species-specific nature. Thus, the discovery of virus-mediated DMSP release presents possibilities heretofore unrecognized.
Acknowledgements. We thank Diana Franks, Christine Hill, Susan Hill, David Kulis, and Frederica Valois for essential help. This work was supported by the Woods Hole Oceanographic Institution Sea Grant Program (R/B-131-PD), National Science Foundation OCE-9411497 (J.W.H.D.), and Michigan State University (B.A.W.). Woods Hole Oceanographic Institution Contribution 9314

\section{LITERATURE CITED}

Andreae $M O$ (1990) Ocean-atmosphere interactions in the global biogeochemical sulfur cycle. Mar Chem 30:1-29

Bates TS, Lamb BK, Guenther A, Dignon J, Stoiber RE (1992) Sulfur emissions to the atmosphere from natural sources. J Atmos Chem 14:315-337

Bratbak G, Egge JK, Helual M (1993) Viral mortality of the marine alga Emiliania huxleyi (Haptophyceae) and termınation of algal blooms. Mar Ecol Prog Ser 93:39-48

Bratbak G, Levasseur M, Michaud S, Cantin G, Fernandez E, Heimdal BR, Heldal M (1995) Viral activity in relation to Emiliania huxleyi blooms: a mechanism of DMSP release? Mar Ecol Prog Ser 128:133-142

Brimblecombe P, Shooter D (1986) Photo-oxidation of dimethylsulphide in aqueous solution. Mar Chem 19: 343-353

Charlson RJ (1995) The vanishing climatic role of dimethyl sulfide. In: Woodwell GM, MacKenzie FT (eds) Biotic feedbacks in the global climatic system. Oxford University Press, New York, p 251-262

Charlson RJ, Lovelock JE, Andreae MO, Warren SG (1987) Oceanic phytoplankton, atmospheric sulphur, cloud albedo and climate. Nature 326:655-661

Christaki U, Belviso S, Dolan JR, Corn M (1996) Assessment of the role of copepods and ciliates in the release to solution of particulate DMSP. Mar Ecol Prog Ser 141:119-127

Cottrell MT, Suttle CA (1991) Wide-spread occurrence and clonal variation in viruses which cause lysis of a cosmopolitan, eukaryotic marine phytoplankter, Micromonas pusilla. Mar Ecol Prog Ser 78:1-9

Cottrell MT, Suttle CA (1993) Production of axenic cultures of Micromonas pusilla (Prasinophyceae) using antibiotics. J Phycol 29:385-387

Cottrell MT, Suttle CA (1995) Dynamics of a lytic virus infecting the photosynthetic marine picoflagellate Micromonas 
pusilla. Limnol Oceanogr 40:730-739

Dacey JWH, Blough NV (1987) Hydroxide decomposition of dimethylsulfoniopropionate to form dimethylsulfide. Geophys Res Lett 14:1246-1249

Dacey JWH, Wakeham SG (1986) Oceanic dimethylsulfide production during zooplankton grazing on phytoplankton Science 233:1314-1316

Falkowski PG, Kim Y, Kolber Z, Wilson C, Wirick C, Cess R (1992) Natural versus anthropogenic factors affecting lowlevel cloud albedo over the North Atlantic. Science 256 $1311-1313$

Fuhrman J (1992) Bacterioplankton roles in cycling of organic matter: the microbial food web. In: Falkowski PG, Woodhead AD (eds) Primary productivity and biogeochemical cycles in the sea. Plenum, New York, p 361-383

Fuhrman JA, Suttle CA (1993) Viruses in marine planktonic systems. Oceanography 6:51-63

Iverson RL, Nearhoof FL, Andreae MO (1989) Production of dimethylsulfonium propionate and dimethylsulfide by phytoplankton in estuarine and coastal waters. Limnol Oceanogr 34:53-67

Jacobsen A, Bratbak G, Heldal M (1996) Isolation and characterization of a virus infecting Phaeocystis pouchetii (Prymnesiophyceael. J Phycol 32:923-927

Keller MD, Bellows WK, Guillard RRL (1989a) Dimethyl sulfide production in marine phytoplankon. In: Saltzman ES, Cooper WJ (eds) Biogenic sulfur in the environment. American Chemical Society, Washington, DC, p 167-182

Keller MD, Bellows WK, Guillard RRL (1989b) Dimethylsulfide production and marine phytoplankton: an additional impact of unusual blooms. In: Cosper EM, Bricelj VM, Carpenter EJ (eds) Novel phytoplankton blooms. Springer-Verlag, New York, p 101-115

Kiene RP (1990) Dimethyl sulfide production from dimethylsulfoniopropionate in coastal seawater samples and bacterial cultures. Appl Environ Microbiol 56:3292-3297

Kiene RP, Bates TS (1990) Biological removal of dimethyl sulphide from sea water. Nature 345:702-705

Koike I, Hara S, Terauchi K, Kogure K (1990) Role of submicrometre particles in the ocean. Nature 345:242-244

Leck C, Larsson U, Bagander LE, Johansson S, Hajdu S (1990) Dimethyl sulfide in the Baltic Sea: annual variability in relation to biological activity. J Geophys Res 95: 3353-3363

Ledyard KM, Dacey JWH (1994) Dimethylsulfide production from dimethylsulfoniopropionate by a marine bacterium. Mar Ecol Prog Ser 110:95-103

Liss PS, Malin G, Turner SM, Holligan PM (1994) Dimethyl sulphide and Phaeocystis: a review. J Mar Sys 5:41-53

Malin G (1996) The role of DMSP and DMS in the global sulfur cycle and climate regulation. In: Kiene RP, Visscher PT, Keller MD, Kirst GO (eds) Biological and environmental

Editorial responsibility: Gary King,

Walpole, Maine, USA chemistry of DMSP and related sulfonium compounds Plenum, New York, p 177-189

Malin G, Turner SM, Liss PS (1992) Sulfur the plankton/climate connection. J Phycol 28:590-597

Mayer JA, Taylor FJR (1979) A virus which lyses the marine nanoflagellate Micromonas pusilla. Nature 281:299-301

Milligan KLD, Cosper EM (1994) Isolation of virus capable of lysing the brown tide microalga, Aureococcus anophagefferens. Science 266:805-807

Nguyen BC, Belviso S, Mihalopoulos N, Gostan J, Nival P (1988) Dimethyl sulfide production during natural phytoplankton blooms. Mar Chem 24:133-141

Proctor LM, Fuhrman JA (1990) Viral mortality of marine bacteria and cyanobacteria. Nature 343:60-62

Proctor LM, Fuhrman JA (1991) Roles of viral infection in organic particle flux. Mar Ecol Prog Ser 69:133-142

Reisser W (1993) Viruses and virus-like particles of freshwater and marine eukaryotic algae-a review. Arch Protistenkde 143:257-265

Shaw GE (1983) Bio-controlled thermostasis involving the sulfur cycle. Clim Change 5:297-303

Starr RC, Zeikus JA (1993) UTEX - the culture collection of algae at the University of Texas at Austin-1993 list of cultures. J Phycol 29(2)(Suppl):1-106

Stefels J, van Boekel WHM (1993) Production of DMS from dissolved DMSP in axenic cultures of the marine phytoplankton species Phaeocystis sp. Mar Ecol Prog Ser 97: $11-18$

Steinke M, Daniel C, Kirst GO (1996) DMSP lyase in marine macro- and microalgae: intraspecific differences in cleavage activity. In: Kiene RP, Visscher PT, Keller MD, Kirst GO (eds) Biological and environmental chemistry of DMSP and related sulfonium compounds. Plenum, New York, p 317-324

Suttle CA, Chan AM (1995) Viruses infecting the marine Prymnesiophyte Chrysochromulina spp : isolation, preliminary characterization and natural abundance. Mar Ecol Prog Ser 118:275-282

Suttle CA, Chan AM, Cottrell MT (1990) Infection of phytoplankton by viruses and reduction of primary productivity. Nature 347:467-469

Taylor BF, Visscher PT (1996) Metabolic pathways involved in DMSP degradation. In: Kiene RP, Visscher PT, Keller MD, Kirst GO (eds) Biological and environmental chemistry of DMSP and related sulfonium compounds. Plenum, New York, p 265-276

Visscher PT, Diaz MR, Taylor BF (1992) Enumeration of bacteria which cleave or demethylate dimethyl sulfoniopropionate in the Caribbean Sea. Mar Ecol Prog Ser 89:293-296

Wolfe GV, Sherr EB, Sherr BF (1994) Release and consumption of DMSP from Emiliania huxleyi during grazing by Oxyrrhis marina. Mar Ecol Prog Ser 111:111-119

Submitted: June 28, 1997; Accepted: July 29, 1997

Proofs received from author(s): November 3, 1997 